\title{
Characteristics of Anemia in Children with HIV Infection
}

\author{
M. Ghozali, ${ }^{1}$ Al Farizi Adhi Sunjaya, ${ }^{2}$ Agnes Rengga Indrati ${ }^{3}$ \\ ${ }^{1}$ Department of Biomedical Sciences Faculty of Medicine Universitas Padjadjaran Bandung, Indonesia, \\ ${ }^{2}$ Faculty of Medicine Universitas Padjadjaran Bandung Indonesia, ${ }^{3}$ Department of Clinical Pathology \\ Faculty of Medicine Universitas Padjadjaran/Dr. Hasan Sadikin Hospital Bandung, Indonesia
}

\begin{abstract}
Anemia is a hematologic complication commonly encountered in HIV patients. Although the severity of anemia is generally mild, anemia has been shown to be a strong risk factor for disease progression, particularly in HIV infected person. With different severity and types of anemia in HIV patients, it is necessary to identify the severity and type of anemia in HIV-infected children, thus helping to determine the prognosis and management of their anemia. The purpose of this study was to describe HIV patient staging infection, co-morbidities, and type of anemia in HIV-infected children based on their therapy. A descriptive quantitative research was conducted in Dr. Hasan Sadikin General Hospital Bandung. Data were collected from patients' medical records diagnosed with HIV between 2015-2017. The severity of anemia was set according to World Health Organization standards in 2011 and the types of anemia were identified from the erythrocyte index on routine hematologic examination. Fortyseven of 73 children had anemia. Based on the severity of anemia, $26 \%$ mild anemia, $60 \%$ moderate anemia, and $15 \%$ severe anemia were found. Subsequently, hypochromic microcytic (40\%), macrocytic (32\%), and normocytic normochromic (28\%) anemia were identified. Considering the direct and indirect mechanism to yield anemia in HIV-infected patients, this double sword symptom becomes the most common complication burdened the growth and development of HIV-infected children. This study made it even more pronounced.
\end{abstract}

Key words: Anemia, Children, HIV

\section{Karakteristik Anemia pada Anak Terinfeksi HIV}

\begin{abstract}
Abstrak
Anemia adalah komplikasi hematologi paling sering ditemukan pada pasien HIV. Meskipun tingkat anemia pada umumnya ringan, anemia telah terbukti menjadi faktor risiko kuat terhadap perkembangan penyakit. Terdapat perbedaan tipe anemia pada pasien HIV dengan etiologi yang berbeda pula sehingga perlu dilakukan identifikasi mengenai tingkat dan tipe anemia pada pasien HIV anak, yang pada akhirnya dapat membantu menentukan prognosis dan penatalaksanaan anemia pada pasien ini. Suatu penelitian deskriptif kuantitatif ini bertujuan mengetahuitingkat dan tipe anemia dengan mengklasifikasikannya berdasarkan komorbiditas pada pasien HIV/ AIDS anak di RSHS tahun 2015-2017 menggunakan data rekam medik pasien pemeriksaan hematologi rutin. Tingkat anemia ditetapkan berdasar atas standar WHO, sementara jenis anemia dilihat dari indeks eritrosit. Sebanyak 73 pasien anak terinfeksi HIV, didapatkan 47 anak mengalami anemia. Tingkat anemia ditemukan anemia ringan (26\%), anemia sedang (60\%), dan anemia berat (15\%). Tipe anemia yang ditemukan adalah normositik normokromik (28\%), makrositik (32\%), dan mikrositik hipokromik (40\%). Tingkat anemia pada pasien HIV anak di RSHS pada umumnya adalah anemia sedang. Tipe anemia terbanyak pada penelitian adalah mikrositik hipokromik.
\end{abstract}

Kata kunci: Anak, anemia, HIV

Correspondence: Mohammad Ghozali dr., M.Sc, Department of Biomedical Sciences Faculty of Medicine Universitas Padjadjaran, Jalan Raya Jatinangor-Sumedang km. 21, Sumedang, West Java, Email: moh.ghozali@unpad.ac.id 


\section{Introduction}

Anemia is the most common hematologic complication in HIV-infected patients with an incidence rate ranging from $1.3 \%$ to $95 \%{ }^{1,2}$ The number of new HIV cases in Indonesia from year to year tends to increase and in 2016 it was reported as many as 41,250 cases with $3.2 \%$ of them occurring in children. ${ }^{3}$

There are many advances in HIV infection management that can facilitate faster diagnosis and improve treatment outcomes, but the complications remain high. Many factors that contribute to the incidence of anemia in HIV patients included nutritional deficiencies such as iron or vitamin B12, opportunistic infections, malignancy, drug therapy, and the direct effects of the HIV virus. ${ }^{4-7}$ Previous studies suggested that anemia is a strong risk factor for disease progression and increase the risk of death if left untreated. ${ }^{1,2,6}$

The previous study had been done in different countries revealed various anemia results depend on their geography, ranging from mild to severe symptom. ${ }^{8}$ However, the knowledge of the characteristic of anemia in HIV children patients has not been widely discussed, particularly in a country with high prevalence of HIV infection, such as Indonesia. The aim of this study was to determine the severity and type of anemia in HIV-infected children, thus providing data to determine the prognosis and provide information for clinical management in HIVinfected children.

\section{Methods}

A descriptive quantitative study was done analyzing hematological data taken from the medical records of patients diagnosed with HIV at the Teratai Clinic of Dr. Hasan Sadikin General Hospital, Bandung. This study included children ( $<18$ years) who had been diagnosed with HIV either receiving ARV drugs, performed hematological checks (hemoglobin and erythrocyte index), from January 2015-June 2017. Patients receiving anemia supplementation and having incomplete medical record data were excluded. This study has been approved by the Ethics Committee of Faculty of Medicine, Universitas Padjadjaran with ethical clearance No. 394/UN6.C.10/PN/2017.

We recorded hematological data using result of Sysmex XT 2000i automatic hemato-analyzer (Sysmex Corp., Tokyo, Japan). We divided the severity of anemia based on hemoglobin level according to World Health Organization into severe, moderate, and mild. ${ }^{9}$ The type of anemia was characterized by erythrocyte index which is the mean corpuscular volume (MCV) and mean corpuscular hemoglobin concentration (MCHC) classified into microcytic hypochromic, normocytic normochromic and macrocytic. ${ }^{4}$.Data descriptively analyzed using Microsoft Excel 2010 Windows Version 14.0.4734.1000.

\section{Results}

Seventy-three data from HIV-infected children was obtained. Of all, 47 patients (64\%) had anemia. The demographic characteristics of HIV children patients was listed in Table 1 . The age of HIV-infected children affected by anemia in this study had a median of 5.2 years old (interquartile range: 2.7-7.3). Of 47 patients with HIV anemia, $76 \%$ of patients had reached stage 4

Table 1 Characteristics of HIV Children Patients

\begin{tabular}{|c|c|c|}
\hline & $(n=47)$ & $\%$ \\
\hline \multicolumn{3}{|l|}{ Sex } \\
\hline Female & 24 & 51 \\
\hline Male & 23 & 49 \\
\hline \multicolumn{3}{|l|}{ Age (years old) } \\
\hline $0,5-4$ & 22 & 47 \\
\hline $5-10$ & 20 & 42 \\
\hline 11-18 & 5 & 11 \\
\hline \multicolumn{3}{|l|}{ HIV } \\
\hline Stage 1 & 3 & 6 \\
\hline Stage 2 & 1 & 2 \\
\hline Stage 3 & 7 & 15 \\
\hline Stage 4 & 36 & 77 \\
\hline \multicolumn{3}{|l|}{ Comorbidities } \\
\hline Pulmonary & 17 & 36 \\
\hline $\begin{array}{l}\text { Tuberculosis } \\
\text { Pneumonia }\end{array}$ & 10 & 21 \\
\hline Oral candidiasis & 7 & 15 \\
\hline Etc. & 5 & 11 \\
\hline \multicolumn{3}{|l|}{ Non-infection } \\
\hline Malnutrition & 19 & 40 \\
\hline Cerebral palsy & 2 & 4 \\
\hline Cardiomyopathy & 2 & 4 \\
\hline Etc. & 10 & 21 \\
\hline
\end{tabular}




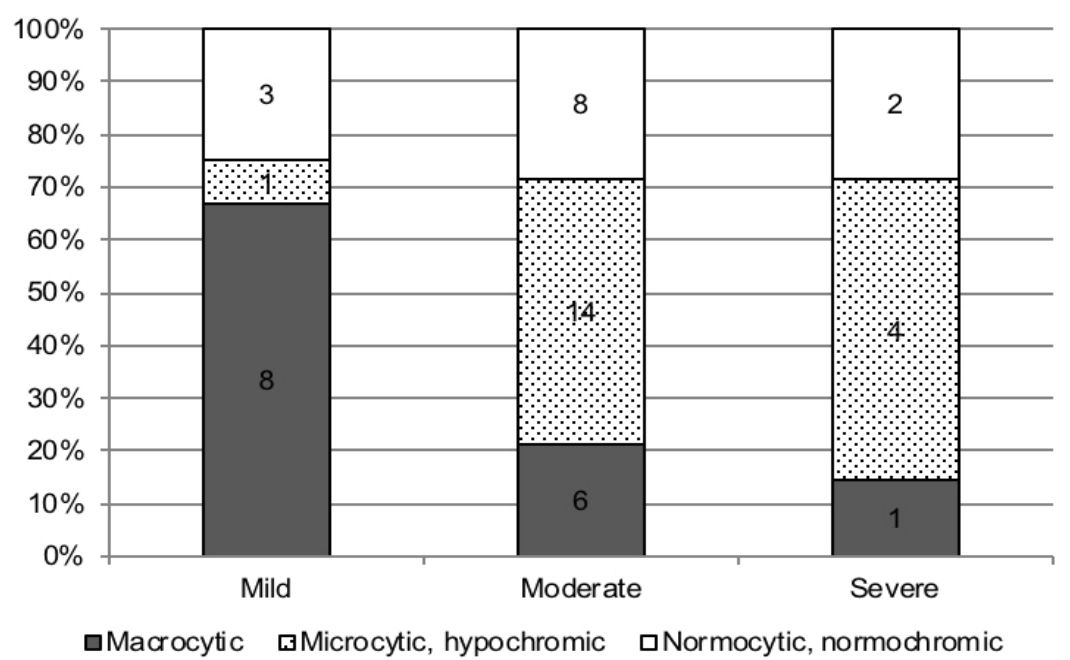

Figure Type of Anemia

HIV. Comorbidities experienced by 37 patients with the most common infectious disease was pulmonary TB with $61 \%$ of patients and the most common non-infectious disease was malnutrition with $40 \%$ of patients. In addition

Table 2 Pharmacological Therapy Used

\begin{tabular}{lcc}
\hline & (n=47) & \% \\
\hline Antiretroviral & 31 & 66 \\
Lamivudine & 30 & 64 \\
Zidovudine & 25 & 53 \\
Nevirapine & 7 & 15 \\
Efavirenz & 2 & 4 \\
Abacavir & 1 & 2 \\
Tenofovir & & \\
Anti-tuberculosis & 12 & 25 \\
Ethambutol & 11 & 23 \\
Rifampicin & 9 & 19 \\
Isoniazid & 6 & 13 \\
Pyrazinamide & & \\
Antibiotics & 31 & 66 \\
Cotrimoxazol & 10 & 21 \\
Gentamicin & 8 & 17 \\
Ampicillin & 6 & 13 \\
Metronidazole & 19 & 40 \\
Others & 12 & 25,5 \\
Antifungal & 26 & 55,3 \\
Others & &
\end{tabular}

to receiving anti-retroviral drugs, HIV patients also received anti-tuberculosis, antibiotics, antifungal, etc., which are shown in Table 2. The most frequently administered retroviral drugs were lamivudine (66\%) and zidovudine (63.8\%).

Hematology profile with a reference value from $\mathrm{WHO}^{9}$ and Greer et al., ${ }^{4}$ was shown in Table 3. The median hemoglobin was of $9.6 \mathrm{~g} /$ $\mathrm{dL}$ (interquartile range: 8.2-10.6), with most of the patients included in moderate anemia. The average MCV value of this study was $83.9 \pm$ $10.7 \mathrm{fl}, \mathrm{MCH} 27.4 \pm 4.2 \mathrm{pg}$, and MCHC $32.9 \pm 1.8 \%$. Figure shows the distribution of severity of anemia based on $\mathrm{WHO}^{9}$ based on erythrocyte morphology (hypochromic microcytic, normocytic normochromic, and macrocytic). ${ }^{4}$

Table 3 Hematological Profile

\begin{tabular}{lc}
\multicolumn{1}{c}{ Parameter } & Patients Value \\
\hline $\begin{array}{l}\text { Hemoglobin, g/dL } \\
\text { (Median, (IQR) }\end{array}$ & $9,6(8,2-10,6)$ \\
MCV, fl & \\
(Mean \pm SD) & $83,9 \pm 10,7$ \\
MCH, pg & \\
(Mean \pm SD) & $27,4 \pm 4,2$ \\
$\begin{array}{l}\text { MCHC, \% } \\
\text { (Mean } \pm S D)\end{array}$ & $32,9 \pm 1,8$ \\
$\begin{array}{l}\text { Erythrocyte, millions } / \mu \mathrm{L} \\
\text { (Mean } \pm \text { SD) }\end{array}$ & $3,4 \pm 0,6$ \\
\hline
\end{tabular}




\section{Discussion}

Anemia has been known to be a clinical problem in HIV patients, suggesting a possible physiological change in regulation of red blood cell formation caused by virus infection ${ }^{1}$. Pulmonary tuberculosis was the most common comorbid infectious disease found in this study. The patients in this study were currently in the middle of various treatments like antiretroviral, anti-tuberculosis, antibiotics, antifungal, and others. Lamivudine and zidovudine were frequently administered in this study. The results of erythrocyte index based on overall mean rate of anemia in HIV patients in this study was hypochromic microcytic.

The mechanism of the occurrence of anemia in HIV infection is known from the study of Redig and Berline $^{1}$ that the HIV has a direct effect through the proteins of the virus in the blood cellforming progenitor cells and the erythropoietin (EPO) response thereby suppressing the formation of red blood cells. Protein p17 in HIV-1 virus mimicry with EPO causing auto-antibody to endogenous EPO. This study showed the anemia has emerged since a young age, although there is no data on the number of viruses infecting, it needs important attention in the management of antivirus administration.

Anemia in HIV-infected patients can also be caused and exacerbated by the side effects of antiretroviral drugs (ARVs). Anemia in HIV patients in antiretroviral treatment improves anemia caused by the HIV virus effectively in both pediatric and adult patients. ${ }^{1}$ Nonetheless, the zidovudine regimen ARV has anemia-related side effects associated with bone marrow suppression. ${ }^{10,11}$ Shet et al. ${ }^{12}$ in their study shown that of 38 non-anemic HIV-infected children, nine children were anemic 6 months later, and 3 of them were attributed to zidovudine-related bone marrow suppression. Most of HIV-infected children in this study were received zidovudine regimen.

Anemia condition certainly affect the quality of life of HIV-infected patients. Anemia can reduce survival rates, accelerate disease progression, and increase mortality in HIV-infected patients. ${ }^{1,6}$ According to WHO, the severity of anemia is differentiated into mild, moderate, and severe. ${ }^{9}$ The severity of anemia found in this study is even worse compared with studies in Ethiopia, which is state with the common severity of anemia is mild $(60.5 \%){ }^{8}$ The different severity of anemia in this study may occur due to several factors such as opportunistic infections, nutritional deficiencies, antiretroviral therapy, zidovudine, and the HIV virus itself. ${ }^{1,6,7}$

HIV virus has the characteristic of infecting CD4 cells so that the cells gradually decrease over time. ${ }^{4}$ The decrease of CD 4 cells will result in easy infection with other infections or opportunistic infections. In this study, we found that most the patients had a history of comorbidities with the most common infectious disease pulmonary TB and the most non-infectious disease was malnutrition. This study did not have complete CD4 cell count data, therefore it is essential to analyze the association of these cells with severity and types of anemia. Chronic inflammation increases cytokines, including IL-1, IL-6, and TNF- $\alpha$-related co-morbid, including anemia. IL-6 has a significant role in the occurrence of anemia through its role in hepcidin regulation ${ }^{1}$. Yaranal et al. ${ }^{13}$ study explains that out of 100 adult pulmonary TB patients, $74 \%$ of patients have anemia associated with a dull response in erythropoiesis in the bone marrow, TNF- $\alpha$ and other cytokines that suppress EPO production.

HIV patients can have any type of anemia and have many risk factors such as micronutrient deficiencies or specific ARV use. Anemia in the HIV population generally has the characteristics of low reticulocyte counts, normochromic and normocytic anemia, normal iron, and EPO response damage, which explains an anemia relationship with inflammation or more commonly referred to as anemia due to chronic infection. ${ }^{1}$ In contrast to this study, the most common type of anemia is microcytic hypochromic. Johannessen's result shown the same proportion that $39.1 \%$ of patients have a type of microcytic hypochromic anemia caused by iron deficiency, ${ }^{10}$ while study in Ethiopia shows that the most common type of anemia is normocytic normochromic 46.5\%. ${ }^{8}$ Folate and vitamin B12 were important for DNA synthesis. Low vitamin B12 and folate status has been associated with poor immunological status and HIV disease progression, while zidovudine causes inhibition of nucleoside reverse transcriptase, in both condition causing delayed DNA replication and accumulate more protein leads to a larger orthochromatic erythroblasts, form macrocytic erythrocytes. ${ }^{14-16}$ In this study, as shown in Figure 1 , although the most common type of anemia is microcytic hypochromic, from 12 patients with mild anemia mostly had macrocytic anemia, this may be due to patients receiving zidovudine therapy, and only 1 patient had comorbid.

According to Shaw adn Friedman ${ }^{17}$ in the inflammatory response, IL-6, hepcidin is 
synthesized. Hepcidin causes sequestration of bio-available iron form into storage form and reduces intestinal absorption of iron. Both processes are caused by the binding of hepcidin to ferroportin. The hepcidin-ferroportin bond causes internalization and degradation of ferroportin, thus trapping iron in cells. The reduction of absorption and sequestration of iron, leading to reduced iron bioavailability to achieve needs such as erythropoiesis. In this study found $60 \%$ of patients had chronic infections and $40 \%$ had malnutrition, which increases the possibility of anemia due to iron deficiency and gave a microcytic hypochromic description.

Limitation of this study that no data regarding cellular and molecular of patients' inflammatory profile such as CD4 count, IL-1, IL-6, and TNF- $\alpha$ related co-morbid. Therefore, further study need to be done in building the profile inflammatory cytokine in HIV-infected children.

In conclusion, considering the direct and indirect mechanism to yield anemia in HIVinfected patients, this double sword symptom becomes the most common complication burdened the patient since their child development. This study made it even more pronounced. The most common type of anemia found in HIV-infected children is hypochromic microcytic. Therefore, it is important to make early diagnosis and provide appropriate treatment in order to reduce the risk of anemia in HIV patients, especially children.

\section{References}

1. Redig AJ, Berliner N. Pathogenesis and clinical implications of HIV-related anemia in 2013. American Society of Hematology. 2013;2013(1):377-81.

2. Sumantri R, Supandiman I, Idjradinata P, Ven Avd, Crevel Rv. Death opportunities for human immunodeficiency virus-acquired immune deficiency syndrome based on combined degree of anemia, body mass index, and number of cluster differentiation MKB. 2012;44(1):50-6.

3. Kemenkes. Health data and information, Indonesia Health Profile 2016. In: RI KK, editor. Jakarta: Kementrian Kesehatan Republik Indonesia; 2017.

4. Greer JP, Arber DA, Glader B, List AF, Robert T, Means J, et al. Wintrobe's Clinical hematology. $13^{\text {th }}$ ed: Philadelphia: Wolters Kluwer Health; 2014.

5. Wisaksana R, Sumantri R, Indrati AR, Zwitser
A, Jusuf H, Mast Qd, et al. Anemia and iron homeostasis in a cohort of HIV-infected patients in Indonesia. BMC Infect Dis. 2011;11(1):1.

6. Meidani M, Rezaei F, Maracy MR, Avijgan M, Tayeri K. Prevalence, severity, and related factors of anemia in HIV/AIDS patients. J Res Med Sci. 2012;17(2):138-42.

7. Takuva S, Maskew M, Brennan AT, Sanne I, MacPhail AP, Fox MP. Anemia among HIVinfected patients initiating antiretroviral therapy in South Africa: improvement in hemoglobin regardless of degree of immunosuppression and the initiating ART regimen. J Trop Med. 2013;2013:1-6.

8. Enawgaw B, Alem M, Melku M, Addis Z, Terefe B, Yitayew G. Prevalence and associated risk factors of anemia among HIV infected children attending Gondar university hospital, Northwest Ethiopia: a cross sectional study. BMC Hematol. 2015; 15(12):1-6.

9. WHO. Haemoglobin concentrations for the diagnosis of anaemia and assessment of severity. Geneva: World Health Organization; 2011.

10. Johannessen A, Naman E, Gundersen SG, Bruun JN. Antiretroviral treatment reverses HIV-associated anemia in rural Tanzania. BMC Infect Dis. 2011;11(1):1-9.

11. Gedefaw L, Yemane T, Sahlemariam Z, Yilma D. Anemia and Risk Factors in HAART Naïve and HAART Experienced HIV Positive Persons in South West Ethiopia: A Comparative Study. PLoS ONE. 2013;8(8):1-5.

12. Shet A, Arumugam K, Rajagopalan N, Dinakar C, Krishnamurthy S, Mehta S, et al. The prevalence and etiology of anemia among HIV-infected children in India. Eur J Pediatr. 2012;171(3):531-40.

13. Yaranal PJ, Umashankar T, Govindareddy $S$, Harish. Hematological Profile in Pulmonary Tuberculosis. Int J Health Rehab Sci. 2013; 2(1):50-5.

14. Nigam JS, Bharti JN, Kumar D, Sharma A. A comparison of hemoglobin A2 levels in untreated and treated groups of HIV Patients on ART including zidovudine. Patholog Research International. 2013;2013:1-3.

15. 15. Koury MJ. Abnormal erythropoiesis and the pathophysiology of chronic anemia. Blood reviews. 2014;28(2):49-66.

16. Ndeezi G, Tumwine JK, Ndugwa CM, Bolann BJ, Tylleskär T. Multiple micronutrient supplementation improves vitamin B12 and folate concentrations of HIV infected 
children in Uganda: a randomized controlled trial. Nutr J. 2011;10(56):1-9.

17. Shaw JG, Friedman JF. Iron deficiency anemia: focus on infectious diseases in lesser developed countries. Anemia. 2011;2011:110. 